\title{
Penyelesaian Kredit Tak Tertagih Berlandaskan Pada Asas Sepenanggungan
}

\author{
Ni Nyoman Alit Widharmayanti¹ ${ }^{\star}$ Putu Eka Dianita Marvilianti Dewi \\ 1,2Program Studi S1 Akuntansi \\ Universitas Pendidikan Ganesha \\ Singaraja, Indonesia
}

e-mail: widharmayanti@gmail.com¹

\begin{abstract}
Riwayat Artikel
Tanggal diajukan

14 Februari2021

Tanggal diterima :

17 Mei 2021

Tanggal

dipublikasikan:

25 Juni 2021

Abstrak

Penelitian ini bertujuan untuk mengetahui (1) proses pengajuan kredit pada Banjar Suka Duka AMER, (2) penyebab terjadinya kredit tak tertagih oleh anggota suka duka AMER, (3) cara menyelesaikan permasalahan kredit yang tidak tertagih oleh anggota suka duka AMER. Metode pengumpulan data diperoleh melalui wawancara, observasi dan dokumentasi yang dilakukan pada Banjar Suka Duka AMER. Pengolahan data yang telah terkumpul kemudian dianalisis melalui reduksi data, penyajian data dan penarikan kesimpulan. Hasil penelitian menunjukkan bahwa (1) Peminjaman kredit oleh anggota Banjar Suka Duka AMER boleh menggunaan nama anggota lain didasari pada rasa saling percaya dan solidaritas yang tinggi antar anggota. Sehingga peminjaman nama anggota dalam pengajuan kredit menjadi hal yang dianggap biasa dan diterima oleh pengurus Banjar Suka Duka AMER. 2) Penyebab terjadinya kredit tak tertagih di Banjar Suka Duka AMER adalah sistem peminjaman kredit yang sangat mudah tanpa menggunakan jaminan dan peraturan yang mengikat anggota untuk membayar kembali kreditnya. (3) Permasalahan kredit tak tertagih di Banjar Suka Duka AMER yang tidak menemukan solusi selama dua tahun akhirnya diselesaikan dengan diterapkannya asas sepenanggungan. Dimana dalam menerapkan asas sepenanggungan ini bunga kredit anggota diputihkan dan pokok kredit dibayarkan semampu anggota membayar.
\end{abstract}

Pengutipan:

Widharmayanti,

N. N. A. \& Dewi,

P. E. D. M.

(2021). Analisis

Penyelesaian

Kredit Tak

Tertagih

Berlandaskan

Pada Asas

Sepenanggungan

(Studi Kasus

Pada Banjar Suka

Duka AMER

Desa Sembiran

Bawah,

Kecamatan

Tejakula,

Kabupaten

Buleleng. Jurnal

Pendidikan

Ekonomi

Undiksha, 13(1)

197-209

http://dx.doi.org/1

0.23887/jipe.v13i

1.32172 ,

Kata Kunci: penyelesaian kredit tak tertagih; asas sepenanggungan.

\begin{abstract}
This study aims to see (1) the process of applying for credit to AMER's Banjar suka duka, (2) the causes of uncollectible credit by AMER joy and sorrow members, (3) how to solve the problem of uncollected credit by AMER's joy and sorrow members. Methods of interview data, observation and documentation carried out in Banjar Suka Duka AMER. Processing the collected data then analyzed through data reduction, data presentation and drawing conclusions. The results showed that (1) the lending of credit by members of the AMER's joy and sorrow may use the names of other members based on mutual trust and solidarity between members. So that the borrowing of members' names in credit applications is commonplace and is accepted by AMER's Banjar Management. 2) The cause of uncollectible credit in the AMER joy and sorrow banjar is a very easy redit lending system without the use of collateral and regulations that bind members to repay their credit. (3) The problem of uncollectible credit in the banjar of AMERica, which did not find a solution for two years, was finally implemented as a cover. Where in applying as penenanggunga in the member credit interest is whitened and the principal of the member is able to pay.
\end{abstract}

Keywords: uncollectible credit settlement; the principle of joint responsibility. 


\section{PENDAHULUAN}

Desa adalah kesatuan masyarakat hukum yang memiliki batas wilayah yang berwenang untuk mengatur dan mengurus urusan pemerintahan, kepentingan masyarakat setempat berdasarkan prakarsa masyarakat, hak asal usul, dan/atau hak tradisional yang diakui dan dihormati dalam sistem pemerintahan Negara Kesatuan Republik Indonesia menurut UU No. 6 tahun 2014 tersebut sesuai dengan hari ini. Di Bali selain terdapat kelurahan juga terdapat yang namanya Desa adat. Desa adat merupakan unit pemerintahan yang dikelola oleh masyarakat adat dan mempunyai hak untuk mengurus wilayah (hak ulayat) dan kehidupan masyarakat dalam lingkungan desa adat. Pitana (1994) menyatakan desa adat memiliki penyebutan yang beragam di berbagai wilayah seperti nagaria, huta, marga, dan negeri. Adapun ciri desa adat di Bali antara lain: 1) mempunyai batas wilayah tertentu yang jelas. Umumnya berupa batas alam seperti sungai, hutan, jurang, bukit dan pantai, 2) mempunyai anggota (krama) yang jelas dengan persyaratan tertentu, 3) Mempunyai khayangan tiga atau khayangan desa (tiga pura desa), atau pura lain yang mempunyai fungsi dan peranan sama dengan khayangan tiga, 4) mempunyai otonomi, baik ke luar maupun ke dalam, 5) mempunyai suatu pemerintahan adat, dengan kepengurusan sendiri (prajuru adat). Salah satu adat yang masih dipertahankan dan diterapkan di Bali adalah penerapan banjar adat atau banjar suka duka.

Desa atau kelurahan di Bali terdiri atas beberapa banjar, berbeda dengan daerah lain di Indonesia, dimana suatu desa terdiri atas beberapa RT/RW. Berdasarkan kamus Kawi-Indonesia, kata banjar berarti baris atau lingkungan, dapat juga diartikan berjajar atau berderet ke samping. Banjar juga berarti kelompok. Dalam bahasa Bali dapat diartikan banjar yaitu membentang. Banjar di Bali adalah kelompok masyarakat yang lebih kecil dari desa, dan menjadi bagian dari desa tersebut, serta merupakan persekutuan hidup sosial baik dalam keadaan senang maupun susah (suka duka). Banjar juga merupakan pengelompokan sosial yang berdasarkan persekutuan hidup setempat atau kesatuan wilayah.

Mengenai asal usul dari banjar, tidak terlepas dengan sejarah dari Bali itu sendiri. Pada zaman prasejarah kehidupan penduduk Bali bisa dikelompokkan menjadi beberapa jenis yaitu masa berburu, masa bercocok tanam dan masa perundagian. Pada masa berburu, masyarakat Bali berpindah-pindah demi mendapatkan makanan (nomaden). Pada masa bercocok tanam, masyarakat Bali mulai mengenal cara mengumpulkan makanan dengan bercocok tanam dan berternak. Pada masa ini mereka mulai hidup berkumpul dan membentuk kelompok masyarakat yang memerlukan segala peraturan kerjasama. Pada masa perundagian, mereka sudah memiliki tempat tinggal dengan pola hidup menetap, serta membentuk kelompokkelompok dan mengatur kehidupannya menurut kebutuhannya yang dipusatkan pada menghasilkan bahan makanan sendiri. Pada masa bercocok tanam dan perundagian, mereka sudah menunjukkan hidup menetap dan berkelompok, serta membentuk suatu masyarakat. Pada masa inilah dikatakan mulai timbulnya banjar yang dipakai untuk menyebutkan persekutuan hidup berkelompok pada suatu tempat atau wilayah.

Sejarah mengenai banjar juga terdapat dalam prasasti Gobleg Pura Desa I, dimana menurut prasasti tersebut, pada tahun 8367 Caka atau 914 Masehi, di Bali sudah ada istilah banjar yang dipakai untuk menyebutkan kelompok-kelompok masyarakat yang hidup di wilayah desa sampai sekarang. Sama halnya dengan desa, banjar di Bali juga dibedakan menjadi 2 yaitu banjar adat dan banjar dinas. Banjar adat keanggotaanya bersifat homogen yaitu beragama sama (Agama Hindu), kegiatan sosialnya meliputi pasuka-dukaan (Suka Duka), diikat dengan awig-awig, dipimpin oleh Kelian Adat, bersifat otonom, diatur 
oleh Perda Prov Bali No. 60 Tahun 1986. Sedangkan banjar dinas keanggotaanya bersifat heterogen, kegiatan sosialnya tergantung dari program pemerintah, diikat oleh peraturan (undang-undang) dari pemerintah dan bersifat vertikal, dipimpin oleh kelian dinas, diatur oleh UU No. 5 Tahun 1979, organisasi terbawah dari Negara Republik Indonesia dan yang terkecil di Bali.

Salah satu banjar adat yang masih dipertahankan dan diterapkan di Bali adalah penerapan banjar adat suka duka. Wihantara (2013) berpendapat bahwa banjar suka duka mengikat anggotanya berdasarkan adat dan tradisi kebudayaan yang bertujuan untuk meningkatkan kebersamaan umat dalam menjalankan segala kegiatan dalam suka maupun duka. Adapun banjar suka duka yang masih tetap ada keberadaannya yaitu Banjar Suka Duka AMER (Amekadi Rahayu) yang terletak di Desa Sembiran Bawah Kecamatan Tejakula Kabupaten Buleleng. Banjar Suka Duka AMER memiliki keunikan tersendiri jika dibandingkan dengan banjar suka duka lain yang ada di Bali. Biasanya banjar suka duka terdiri dari orang-orang yang memang berasal dari desa tempat banjar suka duka berada. Berbeda halnya dengan Banjar Suka Duka AMER yang berada di Desa Sembiran Bawah, pada banjar suka duka ini tidak ada satupun anggotanya merupakan penduduk asli dari Desa Sembiran Bawah, banjar suka duka ini terdiri dari orang-orang rantauan yang berasal dari desa lain yang akhirnya menetap pasca meletusnya Gunung Berapi Agung di Karangasem dan penduduk Desa Bondalem yang memiliki tanah di Desa Sembiran Bawah. Keberagaman asal usul ini tidak menghalangi rasa kekeluargaan antar anggota, justru keberagaman asal ini menjadi alasan untuk para anggota hidup rukun berdampingan dan menumbuhkan rasa sepenanggungan antar anggota.

Awal mulanya ada sekelompok rantauan yang berasal dari Karangasem pasca meletusnya Gunung Agung yang kemudian mengungsi ke Desa Sembiran
Bawah dan lambat laun menetap. Selain perantau, Desa Sembiran Bawah ditinggali oleh orang-orang dari Desa Bondalem yang memiliki tanah di Desa Sembiran Bawah. Suatu ketika ada perantauan yang berasal dari Karangasem yang meninggal dunia namun tidak memiliki kerabat (krama) di Sembiran Bawah sehingga keluarga yang berduka merasa malu untuk meminta tolong kepada rantauan lainnya dan menyembunyikan orang yang meninggal di dalam rumahnya dan keluarga yang berduka tidak terdaftar pada Desa Adat Sembiran sehingga tidak diperkenankan untuk memakamkan orang yang meninggal di desa tersebut. Peristiwa ini memunculkan inisiatif orang-orang dari Desa Bondalem yang merasa iba yang kemudian membantu mempersiapkan pemakaman orang yang meninggal tersebut. Untuk menghindari terulangnya peristiwa seperti itu orangorang dari Desa Bondalem berinisiatif membentuk banjar suka duka yang diberi nama Banjar Suka Duka AMER (Amekadi Rahayu).

Banjar Suka Duka AMER berdiri pada tahun 1960-an yang terdiri dari 11 orang. Kesebelas orang tersebut mengadakan sangkepan (rapat) setiap sebulan sekali dalam sangkepan tersebut akan dipungut iuran yang kemudian iuran tersebut akan diberikan pada anggota yang keluarganya mengalami kedukaan, hal ini menarik perhatian rantauan lainnya sehingga bergabung menjadi anggota Suka Duka. Lambat laun anggota semakin bertambah dan setiap bulan sangkepan rutin diadakan serta tetap memungut iuran dan iuran yang terkumpul tersebut dijadikan uang kas. Seiring berjalannya waktu uang kas terus bertambah sehingga Banjar suka duka bisa meminjamkan uang kas tersebut kepada anggotanya yang membutuhkan dengan syarat minimal Rp500.000 tanpa jaminan jika anggota ingin meminjam uang melebihi syarat tersebut anggota bisa meminjam atau menggunakan nama anggota yang lain untuk meminjam uang, hal ini mengakibatkan terjadinya masalah dikemudian hari karena ada beberapa 
anggota suka duka yang meminjam nama anggota lainnya sehingga bisa meminjam uang lebih dari Rp500.000 tanpa menggunakan jaminan.

Semakin lama, semakin banyak anggota yang meminjam uang dengan jumlah yang banyak dan tanpa jaminan. Memasuki tahun 2016 terjadi berbagai masalah pada banjar adat suka duka AMER khususnya masalah pada keuangan dimana uang yang dipinjam tidak dibayarkan oleh anggota dan bunganya pun sebesar $2 \%$ tidak dibayar, sehingga menyebabkan kas banjar tidak bertambah. Masalah lain yang muncul yaitu ketidakdispilinan anggota banjar, dimana banyak anggota yang meminjam uang tidak memenuhi kewajibannya untuk mengikuti sangkepan, dimana anggota tersebut enggan mengikuti sangkepan karena belum membayar kredit dan bunganya. Pada saat itu, kas banjar masih stabil sehingga kelian banjar memutuskan untuk melakukan renovasi pada bangunan bale banjar dengan menggunakan uang kas banjar. Bangunan yang awalnya direncanakan sederhana kemudian berubah menjadi lebih besar sehingga memerlukan banyak biaya, kemudian kelian banjar mengajukan proposal kepada pemerintah untuk membantu pembangunan bale banjar, tetapi biaya yang diberikan pemerintah masih kurang sehingga diambil keputusan untuk mengajukan kredit di LPD, sehingga kas banjar menjadi minus.

Puncak masalah terjadi pada tahun 2017 ketika bendahara banjar yang juga memiliki kredit melaporkan bahwa buku catatan kredit para anggota hilang, hal ini diutarakan oleh narasumber yaitu Bapak Merta salah satu anggota suka duka AMER beliau menyatakan bahwa selama satu tahun anggota banjar suka duka tidak pernah mengadakan sangkepan, anggota yang memiliki kredit di banjar suka duka juga merasa enggan dan malu untuk ikut sangkepan karena kredit yang dipinjam belum dibayar. Pada tahun 2017 bendahara banjar suka duka yang juga memiliki kredit di banjar suka duka melaporkan hilangnya buku catatan kredit banjar suka duka. Setiap diadakan sangkepan banjar, anggota yang datang tidak lebih dari 10 orang. Hal ini menyebabkan iuran dan pembayaran kredit juga ikut macet, sehingga kepengurusan banjar suka duka saat itu dibubarkan. Hal ini menyebabkan namanama anggota yang memiliki kredit beserta dengan jumlah kreditnya ikut menghilang karena banjar tidak memiliki duplikat lain dari buku catatan kredit tersebut. Hal ini menyebabkan tidak berjalannya sangkepan selama 3 tahun sehingga selama itu pula para anggota tidak membayar kredit dan pemungutan iuran tidak berjalan, dan akhirnya kredit banjar di LPD pun tidak terbayarkan. Hal ini menyebabkan dibubarkannya kepengurusan Banjar Suka Duka AMER pada tahun 2019 dan hutang bunga anggota dihapuskan atau diputihkan. Untuk pengembalian pokok kredit para anggota, kepengurusan Banjar Suka Duka AMER yang baru memberlakukan asas sepenanggungan. Soerjono mendefinisikan asas sepenanggungan merupakan kesadaran dan tanggung jawab anggota komunitas dalam kelompoknya. Asas ini juga diterapkan Banjar Suka Duka AMER dalam pengembalian kredit banjar ke LPD, hal ini diutarakan oleh kelian banjar suka duka AMER periode yang baru yaitu Bapak Made Kardi dalam wawancara dengan beliau, beliau menyatakan bahwa akibat dari hilangnya buku catatan kredit, tidak diketahui siapa saja yang masih memiliki kredit di Banjar Suka Duka AMER, sehingga hutang bunga anggota yang memiliki kredit diputihkan dan kepengurusan banjar suka duka saat itu dibubarkan. Dikepengurusan periode yang baru, iuran kas kembali diadakan. Pokok kredit yang dimiliki oleh anggota dibayarkan seikhlasnya saja, apabila anggota yang mau membayar akan tetap dibayar tetapi untuk anggota yang tidak mau membayar dibiarkan saja. Hutang banjar suka duka di LPD dibayar dengan uang iuran yang dipungut sehingga baik anggota yang berhutang maupun tidak berhutang tetap menanggung pembayaran kredit banjar 
suka duka di LPD. Untuk anggota yang tidak membayar kreditnya di banjar suka duka tidak dikenakan sanksi melainkan diselesaikan secara kekeluargaan dan ditanggung bersama.

Dengan diterapkannya asas sepenanggungan dalam penyelesaian kredit tak tertagih dikepengurusan yang lalu, anggota Banjar Suka Duka AMER mulai displin menghadiri sangkepan. Pada kepengurusan yang baru, semua anggota kembali membayar iuran sangkepan. luran ini kemudian dibagi menjadi dua, setengah untuk membayar utang di LPD dan setengahnya lagi disimpan untuk uang kas yang nantinya dipergunakan untuk membantu anggota yang mengalami kedukaan. Sehingga baik anggota yang berutang maupun anggota yang tidak berutang sama-sama menanggung kredit Banjar Suka Duka AMER di LPD.

Pada penelitian Putri (2017) juga mengangkat mengenai penyelesaian kredit dengan konsep yang sama dalam bahasa yang berbeda. Penelitian Putri (2017) yang berjudul menguak konsep pang pada payu dalam penyelesaian kredit macet ditinjau dari perspektif nasabah pada KSU Banjar Dinas Timbul, Desa Pupuan, Kecamatan Tegalalang, Kabupaten Gianyar, menyatakan penerapan prinsip pang pada payu di KSU Banjar Dinas Timbul telah mencapai keadilan, sesuai dengan arti dari prinsip pang pada payu itu sendiri merupakan suatu model penyelesaian masalah yang tidak menguntungkan atau merugikan kedua belah pihak. Dengan penerapan prinsip pang pada payu ini koperasi merasa diuntungkan sehingga tidak terjadi kredit macet yang sampai membuat koperasi itu menjadi tidak sehat dan masih tetap beroperasi. Sedangkan nasabah juga merasa diuntungkan karena diberikan waktu untuk memenuhi kewajibannya, sehingga nasabah melunasi utangnya meskipun waktu jatuh temponya telah habis.

Kasus kredit tak tertagih juga terjadi pada penelitian Rasmayanti (2017) di Desa Bukti. Dalam penelitian Rasmayanti (2017) yang berjudul konsep menyame braye dalam penyelesaian kredit macet di Lembaga Keuangan Desa, Desa Bukti, Kecamatan Kubutambahan, Kabupaten Buleleng juga menggunakan konsep yang hampir sama dengan penelitian di Banjar Suka Duka AMER. Hasil penelitian ini menyatakan penerapan nilai menyame braya dalam menyelesaikan kredit macet di LPD Desa Bukti diterapkan dengan mengedepankan musyawarah kekeluargaan atau pendekatan langsung kepada masyarakat. Dalam penerapan konsep menyame braye sedikit tidaknya menyadarkan para nasabah akan kewajibannya membayar pinjaman serta mengurangi kerugian yang ditimbulkan akibat adanya kredit macet. Sama halnya dengan ajaran Tat Twam Asi, yang artinya dia adalah kamu, saya adalah kamu, dan semua makhluk adalah sama, sehingga bila kita menolong orang lain dalam hal ini menolong perkembangan LPD Desa Pakraman Bukti berarti juga menolong kita sendiri.

Melihat fenomena tersebut maka penelitian ini mengambil ide untuk menganalisis penerapan asas sepenanggungan dalam penyelesaian kredit tidak tertagih untuk meminimalisir tingkat kredit tak tertagih pada banjar suka duka lainnya. Hasil yang diharapkan adalah untuk membantu pihak banjar dalam mencegah terjadinya kredit tak tertagih yang bisa saja terjadi lagi pada kepengurusan Banjar Suka Duka AMER yang baru dan seberapa besar pengaruh penerapan penyelesaian pembayaran kredit berdasarkan asas sepenanggungan terhadap tingkat pengembalian pokok kredit pada Banjar Suka Duka AMER.

Dari fenomena tersebut penelitian ini sangat menarik untuk mengetahui lebih mendalam tentang penyelesaian kredit tak tertagih berlandaskan asas sepenanggungan. Atas hal tersebut maka penelitian ini mengambil judul "Analisis Penyelesaian Kredit Tak Tertagih Berlandaskan Pada Asas Sepenanggungan (Studi Kasus Pada Banjar Suka Duka 
AMER Desa Sembiran Bawah, Kecamatan Tejakula, Kabupaten Buleleng)".

\section{METODE}

Pendekatan yang digunakan dalam penelitian ini adalah pendekatan kualitatif. Sugiyono (2012) menjelaskan pendekatan kualitatif adalah suatu proses penelitian dan pemahaman yang berdasarkan pada metodologi yang menyelidiki suatu fenomena sosial dan masalah manusia. Data yang dicari penelitian ini berupa penyelesaian kredit tidak terbayar anggota Banjar Suka Duka AMER yang berlandaskan asas sepenanggungan. Data primer dalam penelitian ini diperoleh dengan wawancara dan observasi dari Kelian Banjar periode lama, bendahara Banjar Suka Duka AMER periode baru, anggota Banjar Suka Duka AMER yang memiliki kredit, dan anggota Banjar Suka Duka AMER yang tidak memiliki kredit. Sumber data sekunder dalam penelitian ini diperoleh dari pihak intern maupun ekstern Banjar Suka Duka AMER yang dapat dilihat dari dokumen Banjar Suka Duka AMER yaitu struktur organisasi dan catatan kredit Banjar Suka-Duka AMER, literatur-literatur dan penelitian terdahulu, serta informasi lain yang mendukung penelitian ini. Penelitian ini menggunakan teknik analisis data model interaktif yaitu dimulai dari tahapan pengumpulan data dilanjutkan dengan reduksi data, display data dan tahapan akhir yaitu penarikan kesimpulan.

Dalam penelitian untuk mendapatkan keabsahan data dilakukan dengan triangulasi. Adapun triangulasi adalah teknik pemeriksaan keabsahan data yang memanfaatkan sesuatu yang lain di luar data untuk itu untuk keperluan pengecekan atau sebagai pembanding terhadap data itu. Tringulasi yang digunakan dalam penelitian ini adalah triangulasi sumber, triangulasi metode dan triangulasi waktu.

\section{HASIL DAN PEMBAHASAN}

Gambaran Umum Banjar Suka Duka AMER
Banjar Suka Duka AMER terletak di Desa Sembiran Bawah Kecamatan Tejakula Kabupaten Buleleng Provinsi Bali. Banjar suka duka ini didirikan berdasarkan inisiatif dari 11 orang yang merantau ke Desa Sembiran Bawah pasca meletusnya Gunung berapi Agung pada tahun 1963 Banjar Suka Duka AMER tercatat terdiri dari 169 anggota, namun hanya 150 anggota yang masih aktif. Anggota banjar suka duka terbagi atas dua masyarakat yaitu masyarakat yang berasal dari Desa Bondalem dan masyarakat yang berasal dari Karangasem.

Sejarah terbentuknya Banjar Suka Duka AMER berawal dari meletusnya Gunung Berapi Agung di Karangasem pada tahun 1963, yang menyebabkan banyak masyarakat yang tinggal di sekitar Gunung Agung kehilangan tempat tinggal, sehingga masyarakat tersebut mencari tempat baru untuk melanjutkan hidupnya. Kemudian beberapa masyarakat tersebut datang ke Desa Sembiran, Desa Sembiran dibagi atas dua daerah yaitu Daerah Sembiran Atas dan Daerah Sembiran Bawah. Daerah Sembiran Atas ditinggali oleh masyarakat asli yang dikenal dengan penduduk Bali Aga (Bali asli), sedangkan daerah Sembiran Bawah hanya sebuah kebun yang tidak ada penduduknya. Kemudian pasca meletusnya Gunung Berapi Agung banyak masyarakat Karangasem yang datang kemudian membeli tanah di Desa Sembiran Bawah dan tinggal di desa tersebut. Selain masyarakat dari Karagasem, ada juga masyarakat dari Desa Bondalem, yang pada tahun 1960-an banyak masyarakat Desa Bondalem menjadi saudagar jeruk membeli tanah di Desa Sembiran Bawah dan membangun rumah di desa tersebut kemudian menetap. Sehingga Desa Sembiran Bawah ditinggali oleh penduduk rantauan. Penduduk yang berasal dari Bondalem tetap mendaftarakan kependudukannya di Bondalem sedangkan penduduk dari karangasem mendaftarkan kependudukannya di Desa Sembiran Atas.

Organisasi Banjar Suka Duka AMER terdiri dari Ketua/Kelian Banjar, Kerohanian, 
penasehat, sekretaris, bendahara, tempek 1, tempek 2, dan tempek 3. Kelian Banjar Suka Duka AMER memiliki fungsi menentukan keputusan pemberian kredit pada anggota, memimpin sangkepan yang diadakan tiap minggu wage, dan mengambil keputusan ketika sangkepan banjar diadakan. Pada bagaian kerohanian, orang yang bertanggung jawab pada bagian ini adalah "pemangku" yang ada di Desa Sembiran Bawah yang hanya memimpin upacara di Banjar Suka Duka AMER saja (pemangku banjar). Penasehat pada Banjar Suka Duka AMER memiliki fungsi untuk mengontrol dan mengawasi semua kebijakan yang dibuat oleh Banjar Suka Duka AMER, penasehat juga memiliki tugas mengkritisi kepengurusan dari banjar suka duka, serta mengevaluasi kepengurusan di akhir periode. Pada bagian sekretaris berfungsi untuk mencatat segala iuran yang masuk, pencatatan keluar masuknya uang kas juga merupakan tugas dari sekretaris termasuk pencatatan pengeluaran kas untuk kredit anggota dan pencatatan pemasukan kas dari pembayaran kredit serta bunga oleh anggota, sehingga sekretaris juga mengetahui siapa saja anggota yang memiliki kredit di banjar suka duka. Bagian bendahara banjar suka duka hanya bertugas untuk memegang uang kas serta mengeluarkan uang sebagai kredit yang diberikan kepada anggota dan menerima uang kas yang masuk serta pembayaran kredit dan bunganya, bendahara tidak bertugas pada pencatatannya. Ketua tempek memiliki fungsi untuk menyebarkan semua informasi yang keluar dari Banjar Suka Duka AMER kepada semua anggota banjar suka duka, ketua tempek juga berfungsi untuk memungut iuran kedukaaan yang diberikan sebagai santunan kepada keluarga anggota Banjar Suka Duka AMER yang kerabatnya meninggal.

Sistem Pengajuan Kredit Banjar Suka Duka AMER yang Boleh Meminjam Nama Anggota Lain
Pada Banjar Suka Duka AMER peminjaman kredit yang diajukan oleh anggota termasuk sangat mudah, karena tidak memerlukan syarat-syarat tertentu seperti pengajuan kredit pada umumnya, syarat penting pengajuan kredit hanya si peminjam harus menjadi anggota tetap banjar suka duka AMER. Pengajuan kredit oleh anggota bisa dilakukan saat sangkepan banjar diadakan. Pada saat sangkepan, bendahara banjar akan memungut iuran kepada semua peserta sangkepan sebanyak Rp.5000 kepada anggota banjar yang hadir, untuk anggota banjar yang tidak hadir akan dikenakan iuran dan denda sebanyak Rp.5000 jadi total yang harus dibayarkan oleh anggota yang tidak hadir sebanyak Rp.10.000 dan dibayarkan pada saat sangkepan bulan berikutnya. Uang yang terkumpul kemudian akan dihitung pada saat itu juga dan pada akhir sangkepan beberapa anggota yang akan meminjam kredit didata kemudian diberikan tanpa ada jaminan. Besaran kredit yang diberikan mulai dari Rp500.000 dan maksimal Rp.1.000.000. Pada proses peminjaman ini, tidak ada aturan/awig-awig yang terlalu mengikat. Anggota dibebaskan tenggang waktu pengembaliannya dengan bunga sebesar $2 \%$.

Pada proses peminjaman kredit, anggota boleh meminjam nama anggota lainnya untuk mengajukan kredit. Sehingga satu anggota bisa saja meminjam uang lebih dari $\quad \operatorname{Rp~1.000.000~dengan~jalan~}$ meminjam nama anggota lain tanpa menyertakan jaminan kepada banjar suka duka. Meskipun pengurus Banjar Suka Duka AMER tahu bahwa si anggota meminjam nama anggota yang lain, pengurus tetap memberikan kredit kepada angggota tersebut, dan anggota yang dipinjam namanya pun tidak merasa keberatan. Hal ini didasarkan pada rasa saling percaya dan solidaritas yang tinggi antar anggota Banjar Suka Duka AMER. Hal ini dipaparkan oleh Bapak Nyoman Korda sebagai Bendahara Banjar Suka Duka AMER periode yang baru, beliau menyatakan bahwa: 
"pada peiode sebelumnya, sewaktu bendahara yang menghilangkan buku catatan piutang masih menjabat, peminjaman kredit oleh anggota sangat mudah. Anggota hanya perlu memberitahukan kepada pengurus diakhir sangkepan apabila dia memerlukan uang. Kalau uangnya ada ya langsung diberikan kepada anggota yang perlu. Uang yang diberikan itu adalah uang kas iuran yang dipungut. Semisalkan pada saat itu ada uang sebesar Rp.4.000.000, pengurus akan bertanya siapa yang mau meminjam. Pada saat peminjaman, anggota yang merasa kurang, akan meminjam nama anggota lainnya dan diajukan oleh anggota itu sendiri. Pengurus tau, kalau si peminjam ini menggunakan nama anggota lain tapi tetap diberikan. Nanti setelah sangkepan berikutnya, didata nama-nama yang meminjam, si anggota yang dipinjam namanya ini akhirnya tau namanya dipinjam, tapi dia tidak merasa keberatan dan dibiarkan saja. Namanya juga banjar suka duka, suka kita tanggung bersama dukapun tanggung bersama. Sukanya pada saat pinjam uang, dukanya pada saat ada kematian".

Rasa percaya dan rasa kekeluargaan antar anggota banjar suka duka AMER sangat erat, hal ini disebabkan karena semua anggota sama-sama perantau dari wilayah yang sama dan selama bertahun-tahun mereka hidup berdampingan saling membantu. Sehingga peminjaman kredit ini pun dilakukan dengan sistem kekeluargaan dan saling percaya. Seperti yang dikatakan oleh Bapak Nyoman Korda pada saat wawancara, beliau menyampaikan:

"mau bagaimana lagi, walaupun kita tau sistem ini tidak benar tapi tetap saja dibiarkan oleh pengurus dan anggota lainnya. Be care munyi masyarakat e dini, masi sing ajak nyen, pade-pade nyame Bondalem jak pade-pade nyame uli Karangasem. Nah bang be, kuda kenape masi jak mekejang naggung resikone".

"mau bagaimana lagi, walaupun kita tau sistem ini tidak benar tapi tetap saja dibiarkan oleh pengurus dan anggota lainnya. Seperti perkataan orang-oramg disini, juga kita semua saudara, sama-sama dari Bondalem dan sama-sama dari Karangasem. Yasudah biarkan saja, apapun yang terjadi nanti akan kita tanggung bersama.

Berdasarkan pada hasil wawancara dapat disimpulkan bahwa yang mendasari peminajamn kredit oleh anggota dengan menggunakan nama anggota lain yaitu anggota Banjar Suka Duka AMER telah hidup berdampingan sejak lama dan merupakan perantau sehingga menumbuhkan rasa kekeluargaan dan solidaritas yang tinggi sehingga saling mempercayai satu sama lainnya.

Penyebab Terjadinya Kredit Tidak Tertagih
di Banjar Suka Duka AMER
Pada tahun 2016 peminjaman kredit di Banjar Suka Duka AMER masih berjalan seperti biasa. Anggota yang mengajukan kredit masih bisa menggunakan nama anggota lain untuk mendapatkan kredit yang lebih banyak. Hal ini menyebabkan banyak uang kas yang keluar dan tidak ada jaminan pada uang kas yang dipinjamkan. Pada pertengan tahun ini juga banyak anggota yang tidak bisa membayar bunga kredit tersebut. Hal ini menyebabkan muncul permasalahan di Banjar Suka Duka AMER, khususnya permasalahan pada bagian keuangan. Tidak tertagihnya bunga kredit meyebabkan kas Banjar Suka Duka AMER tidak kembali. Tetapi permasalahan ini masih bisa diatasi oleh pengurus dengan jalan tetap mengadakan sangkepan dan tetap memungut uang iuran dari anggota sehingga uang kas bisa bertambah dari iuran.

Masih pada tahun yang sama kelian banjar menganggap bahwa keuangan Banjar Suka Duka AMER masih baik-baik saja, sehingga kelian banjar berinisiatif untuk melakukan renovasi terhadap bangunan bale banjar. Dana yang dipakai adalah uang iuran yang selama ini terkumpul menjadi uang kas. Awalnya 
rencana renovasi didesign sederhana, tetapi saat renovasi berjalan kelian banjar merubah renovasi tersebut dan merencanakan design bangunan berlantai dua. Hal ini menyebabkan dana yang awalnya cukup menjadi kurang sehingga kelian banjar berinisiatif membuat proposal yang kemudian diajukan ke pemerintah untuk memperoleh dana renovasi. Setelah proposal diajukan dan di terima, dana dari pemerintah didapatkan dan digunakan untuk pembangunan bale banjar. Tetapi, uang dari pemerintah ini pun tidak cukup dipakai untuk menyelesaikan renovasi bale banjar. Sehingga diadakanlah sangkepan seluruh anggota banjar suka duka AMER untuk mediskusikan penyelesaian masalah tersebut. Pada sangkepan tersebut diperoleh keputusan bahwa banjar suka duka AMER akan meminjam uang di LPD dengan menggunakan sertifikat tanah bale banjar sebagai jaminannya. Hal ini dipaparkan oleh Bapak Made Kardi. Berdasarkan wawancara, narasumber berpendapat bahwa:

"pada tahun 2016 sewaktu kelian banjar periode sebelumnya masih menjabat sebagai kelian banjar, beliau melakukan renovasi pada bale banjar. Uang yang digunakan adalah uang kas, pertama renovasi direncanakan hanya mengganti atap dan lantai saja. Tetapi, tiba-tiba bangunannya berubah, bagian atap malah direncanakan dicor dengan semen katanya beliau berencana untuk membagun bale banjar dua lantai. Ditengah-tengah pembangunan, akhirnya macet karena uang kasnya sudah habis, sedangkan bangunan belum setengah jadi. Kemudian kelian banjar ini membuat proposal yang diajukan ke pemerintah sehingga mendapat dana sekitar lima belas juta, dan dana ini masih kurang untuk menyelesaikan pembangunan. Akhirnya diadakanlah sangkepan banjar sehingga diperoleh keputusan untuk meminjam uang di LPD sebesar enam puluh juta dan renovasi selesai. Tetapi tetap saja bangunannya satu lantai karena dana yang dipinjampun tidak mencukupi untuk membuat bangunan dua lantai".

Setelah masalah renovasi, muncul lagi masalah keuangan di Banjar Suka Duka AMER. Masalah ini merupakan masalah puncak yang terjadi pada periode kepengurusan Banjar Suka Duka AMER tahun 2016. Pada tahun yang sama, bendahara Banjar Suka Duka AMER yang juga memiliki jumlah kredit yang banyak melaporkan bahwa semua buku administrasi Banjar Suka Duka AMER hilang, termasuk buku cacatan kredit. Hal ini mengakibatkan nama-nama anggota yang meminjam kredit beserta dengan jumlah kreditnya ikut menghilang. Muncul kecurigaan bahwa buku ini sebenarnya tidak hilang, melainkan tetap disimpan tetapi dinyatakan hilang oleh bendahara. Sehingga dari tahun 2016 sampai tahun 2019 banyak anggota yang memiliki kredit tidak bertanggungjawab untuk membayar bunga kredit beserta pokok kreditnya. Dari akhir tahun 2016 sampai dengan tahun 2019 banyak anggota banjar suka duka yang tidak ikut datang sangkepan bulanan. Hal ini disebabkan anggota yang tidak membayar kredit enggan mengikuti sangkepan. Sehingga dari akhir tahun 2016 sampai 2019 uang kas Banjar Suka Duka AMER tidak bertambah dan kredit pun tidak tertagih. Hal ini mengakibatkan terjadinya kredit tak tertagih di Banjar Suka Duka AMER. Kasmir (2012) menjelaskan kredit tak tertagih ialah kredit yang tidak terbayar atau kredit dimana debitnya tidak dapat memenuhi persyaratan yang diperjanjikan, misalnya persyaratan pembayaran bunga, pengambilan pokok pinjaman, peningkatan margin deposit, pengikatan dan peningkatan agunan, dan sebagainya.

Dengan tidak tertagihnya kredit anggota Banjar Suka Duka AMER dan macetnya sangkepan tiap bulan, menyebabkan kas Banjar Suka Duka AMER minus. Hal ini menyebabkan hutang Banjar Suka Duka AMER di LPD juga ikut tidak terbayar. Selama dua tahun dari tahun 2017 sampai tahun 2019, Banjar Suka Duka AMER tidak mampu membayar kredit 
banjar di LPD, sehingga hutang yang awalnya sudah berkurang menjadi 30 juta kembali menjadi 50 juta banjar tidak mampu membayar bunga dan pokok hutang. Sehingga pada tahun 2019 bunga kredit anggota banjar suka duka AMER yang berhutang diputihkan, pokok bunga dibayar seikhlasnya saja dan kepengurusan Banjar Suka Duka AMER pada saat itu dibubarkan. $\mathrm{Hal}$ ini bertujuan untuk mengaktifkan kembali sangkepan banjar sehingga iuran dapat dipungut kembali dan hutang banjar di LPD bisa dibayar. Penjelasan ini dipaparkan oleh Bapak Nyoman Korda selaku bendahara Banjar Suka Duka AMER yang baru, beliau menyatakan bahwa:

"dari tahun 2017 sampai 2019 hutang di LPD tidak mampu dibayar sampe bunga hutang menumpuk, hutang yang awalnya masih 30 juta kembali membengkak sampai hampir mencapai 60 juta. Karena anggota tidak mau membayar bunga dan ikut sangkepan Banjar Suka Duka AMER tidak memiliki kas untuk membayar bunga dan pokok hutang. Karena buku catatan kredit anggota hilang, istilah balinya anggone lege ken anggotane ilang buku ne, jeg bungan pis sing bayah e pokok sg bayahe, kayang sangkepan sing teke. Jaminan sing ade masi, aluhange ken anggota ne, malah anggota ne sampai ngomong, nah dimatine be bayah utang santunane potong. Ulian irage pade nyame ajak mebanjar sing juari masi lakar maksaang nagihin, apalgi be orange sing ngelah, sanksi banjar masi sing ade nak medasar ulian saling ngugu. Sampai akhire pengawas ngae sangkepan pembubaran anggota mare mekejang teke sangkep, disangkepane nto maan keputusan pemutihan bunga uang dan pokok kredit dikembalikan seikhlasnya sesuai catatan seadanya ne baange jak bendahara ne".

Setelah pembubaran kepengurusan selesai dibentuklah kepengurusan yang baru. Pada kepengurusan yang baru ini, kredit anggota Banjar Suka Duka AMER kemudian diselesaikan dengan cara kekeluargaan.
Penyelesaian Kredit Tak Tertagih Berlandaskan Pada Asas Sepenanggungan di Banjar Suka Duka AMER

Pada penyelesaian kredit tak tertagih di Banjar Suka Duka AMER juga menggunakan asas sepenanggungan. Rasa saling percaya dan solidaritas yang tinggi antar anggota yang menjadi dasar peminjaman kredit tanpa jaminan juga menjadi dasar penyelesaian permasalahan keuangan yang dialami oleh Banjar Suka Duka AMER. pada tahun 2019 sangkepan banjar suka duka masih macet. Sehingga pengurus mengambil keputusan untuk memutihkan bunga kredit dan meminta kepada anggota yang memiliki kredit untuk mengembalikan pokok kredit semampu dan seikhlas anggota saja. Pemutihan kredit ini dilakukan dengan tujuan untuk memancing anggota yang memiliki kredit untuk kembali mengikuti sangkepan kembali sehingga banjar suka duka bisa memungut iuran untuk membayar hutang banjar di LPD.

Setelah kepengurusan lama dibubarkan dan bunga kredit anggota Banjar Suka Duka AMER diputihkan, dibentuk lagi kepengurusan yang baru. Pada kepengurusan yang baru bendahara periode yang lalu memberikan catatan kasar mengenai nama-nama anggota yang mempunyai kredit di Banjar Suka Duka AMER. Pada awal sangkepan pengurus banjar periode yang baru dilakukan pendataan ulang bagi anggota yang meimiliki kredit dengan mengkonfirmasi satu persatu anggota berdasarkan catatan yang diberikan oleh bendahara periode yang lama. Hal ini dinyatakan oleh Bapak Nyoman Korda sebagai bendahara periode yang baru, beliau menyatakan bahwa:

"setelah 2 tahun dari akhir 2016 sampai 2019 sangkepan benar-benar macet. Pernah diadakan sangkepan tapi yang datang itu tidak lebih dari 10 orang. Kejadian ini sebelum bunga uang diputihkan. Karena sudah semakin lama permasalahan kredit ini tidak menemukan solusi akhirnya diambilah keputusan, yasudah bunga uang kita putihkan saja. Biarkan pokok bunga saja dikembalikan 
seikhlasnya saja, yang penting sangkepan bisa jalan lagi. Pada waktu dibentuk pengurus yang baru, akhirnya bendahara yang lama memberikan catatan orek-orek saja siapa-siapa yang pinjam uang, setelah itu dikonfirmasi satu-satu apa benar punya hutang. Yang sadar ya ngaku yang gak sadar yasudah biarkan saja. Toh juga lda Sang Hyang Widi Wasa yang tau. Tidak enak rasanya kalau kita terlalu ributkan masalah ini, karena kita semua saudara".

Anggota Banjar Suka Duka AMER dibebaskan waktu pengembalian kredit yang dipinjam. Bagi anggota yang sadar akan kreditnya, mereka membayar seikhlasnya dan semampu mereka membayar. Sedangkan untuk anggota yang tidak mampu membayar dan kurang sadar akan kreditnya dibanjar mereka tidak membayar kreditnya. Hal ini dibiarkan oleh pengurus suka duka AMER, karena prinsip mereka kredit tersebut pasti akan kembali ke kas Banjar Suka Duka AMER ketika si anggota meninggal, santunan yang didapatkan oleh keluarga si anggota akan langsung dipotong sebesar kredit yang dipinjam tanpa menghitung bunga uang. Tidak ada sanksi khusus yang diberikan oleh Banjar Suka Duka AMER kepada anggota yang tidak membayar kreditnya.

Selain dengan cara mengadakan sangkepan, Banjar Suka Duka AMER menyelesaikan kredit tak tertagihnya dengan cara menugaskan setiap ketua tempek memungut santunan kedukaan per anggota, ketika ada anggota yang meninggal. Santunan yang awalnya hanya dipungut sebesar Rp.25.000 berubah menjadi Rp.30.000 per anggota. Santunan yang Rp.25.000 akan diserahkan ke anggota suka duka yang meninggal dan sisanya Rp.5000 akan dikumpulkan dan digunakan untuk membayar hutang banjar di LPD. Baik anggota yang tidak punya kredit maupun punya kredit dibanjar suka duka sama-sama menanggung kredit tak tertagih tersebut.

Dengan diterapkan asas sepenanggungan pada penyelesaian kredit Banjar Suka Duka AMER, sangkepan bulanan bisa kembali dilaksanakan. Pada sangkepan tersebut uang iuran kembali dipungut kepada anggota dan denda bagi anggota yang tidak bisa hadir kembali diberlakukan. Baik anggota yang memiliki kredit maupun yang tidak memiliki kredit tetap dipungut iuran. Iuran ini kemudian digunakan oleh Banjar Suka Duka AMER untuk membayarkan kredit banjar di LPD.

Berdasarkan hasil penelitian dapat disimpulkan bahwa penyelesaian kredit banjar suka duka AMER baik kredit dari anggota ke Banjar Suka Duka AMER diselesaikan dengan asas sepenanggungan, rasa kekeluargaan dan solidaritas antar anggota yang tinggi karena pada prinsipnya semua anggota banjar adalah saudara sehingga suka maupun duka yang dihadapi akan ditanggung bersama. Dengan diterapkannya asas sepenanggungan pada penyelesaian kredit anggota juga berdampak pada penyelesaian kredit banjar ke LPD sehingga banjar mampu membayar kembali kreditnya di LPD.

\section{SIMPULAN DAN SARAN \\ Simpulan}

Berdasarkan hasil penelitian yang telah dibahas, maka dapat disimpulkan bahwa: (1) peminjaman kredit oleh anggota Banjar Suka Duka AMER boleh menggunaan nama anggota lain didasari pada rasa saling percaya dan solidaritas yang tinngi antar anggota. Sehingga peminjaman nama anggota dalam pengajuan kredit menjadi hal yang dianggap biasa dan diterima oleh pengurus Banjar Suka Duka AMER. Rasa saling percaya dan solidaritas ini tumbuh karena anggota banjar suka duka merupakan masyarakat yang sama-sama pendatang di Desa Sembiran Bawah. Sehingga mereka berprinsip semua adalah saudara, susah senang akan ditanggung bersama. (2) Penyebab terjadinya kredit tak tertagih di Banjar Suka Duka AMER adalah sistem peminjaman kredit yang sangat mudah tanpa menggunakan jaminan dan peraturan 
yang mengikat anggota untuk membayar kembali kreditnya. Peminjaman kredit ini hanya didasarkan pada rasa saling percaya antar anggota, sehingga menyebabkan anggota yang meminjam kredit berani untuk tidak membayar pokok kredit dan bunga kredit. Hilangnya buku catatan kredit para anggota juga menjadi alasan kuat tak tertagihnya kredit Banjar Suka Duka AMER. Dengan hilangnya buku catatan kredit, memberikan peluang kepada anggota untuk tidak membayar kreditnya. Macetnya sangkepan selama dua tahun menyebabkan semua kredit anggota Banjar Suka Duka AMER tidak tertagih sehingga berujung pada diterapkannya asas sepenanggungan dalam penyelesaian kredit ini. (3) Permasalahan kredit tak tertagih di banjar suka duka AMER yang tidak menemukan solusi selama dua tahun akhirnya diselesaikan dengan diterapkannya asas sepenanggungan. Dimana dalam menerapkan asas sepenanggungan ini bunga kredit anggota diputihkan dan pokok kredit dibayarkan semampu anggota membayar. Pada sangkepan-sangkepan yang diadakan banjar pada pengurus yang baru baik anggota yang memilii kredit maupun tidak tetap membayar pungutan iuran dengan jumlah yang sama. Dalam penyelesaian hutang banjar di LPD juga diselesaikan dengan asas sepenanggungan. Dimana, semua anggota ikut menanggung pembayaran pembayaran hutang ini dengan jumlah pungutan iuran yang sama serta santunan kematian yang lebih besar dari biasanya. Dengan diterapkannya asas sepenanggungan ini, permasalahan kredit tak tertagih di Banjar Suka Duka AMER yang tidak mampu diselesaikan selama dua tahun akhirnya dapat diselesaikan sehingga Banjar Suka Duka AMER bisa beraktivitas normal seperti sebelum terjadinya kredit tak tertagih.

\section{Saran}

Dari kesimpulan yang telah dikemukakkan di atas, maka ada beberapa saran yang dapat penelitian ini sampaikan antara lain: (1) Pengurus Banjar Suka Duka AMER untuk tetap menerapkan asas sepenanggungan apabila terjadi permsalahan yang sama dikemudian hari mengingat rasa solidaritas dan kekeluargaan antar anggota banjar sangat tinggi. Tetapi, untuk menghindari terulangnya kasus kredit tidak tertagih di Banjar Suka Duka AMER, ada baiknya apabila sistem peminjaman kredit dibarengi dengan sistem pengendalian internal yang baik, sehingga antara anggota dan pengurus Banjar Suka Duka AMER tidak dirugikan. (2) Bagi anggota Banjar Suka Duka AMER, hendaknya mampu menjalin serta meningkatkan kualitas komunikasi yang baik antar anggota dengan pengurus khususnya pada penyelesaian kredit, sehingga menciptakan sebuah kondisi yang baik dan memberikan pengaruh positif untuk mematuhi segala kewajiban anggota yang diterapkan oleh Banjar Suka Duka AMER yang telah disepakati, dan turut berpartisipasi secara aktif dalam segala kegiatan yang berkaitan dengan Banjar Suka Duka AMER. (3) Bagi peneliti selanjutnya yang tertarik menggunakan tema penelitian yang sama, agar mengambil objek penelitian yang berbeda sehingga menghasilkan penelitian yang lebih unik, menarik dan dapat bermanfaat bagi banjar atau lembaga keuangan dalam hal menyelesaikan masalah kredit yang tidak tertagih.

\section{DAFTAR PUSTAKA}

Kasmir. (2012). Dasar-Dasar Perbankan. Jakarta: Grapindo Prasada.

Pitana, I. G. (1994). Dinamika Masyarakat dan Kebudayaan Bali. Denpasar: Balipost.

Putri, M. S. (2017). Menguak Konsep "Pang Pada Payu" Dalam Penyelesaian Kredit Macet Ditinjau dari Persfektif Nasabah (Studi Kasus Pada KSU banjar Dinas Timbul, Desa Pupuan, Kecamatan Tegallalang, Kabupaten Gianyar). E-Journal S1 Akuntansi, 8(2). Rasmayanti, D. (2017). Konsep Menyame Braye Dalam penyelesaian Kredit 
Macet di Lembaga Perkreditan Desa (Studi Kasus di Lembaga Perkreditan Desa, Desa Bukti, Kecamatan Kubutambahan, Kabupaten Buleleng). E-Journal S1 Akuntansi, 8(2).

Soerjono, S. (1983). Teori Sosiologi Tentang Perubahan Sosial. Surabaya: Ghalia Indonesia.

Sugiyono. (2012). Metode Penelitian. PT. Jakarta: Bumi Aksara. 